THE EMERGENCE

OF REGIONAL ICT

REGULATORY SPACES

Raúl

L. Katz

$2014 / 44$

Raúl L. Katz

Columbia Institute for Tele-Information/

Columbia Business School

rk2377@columbia.edu 
IBEI WORKING PAPERS

TELEFONICA CHAIR SERIES

2014/44

The Emergence of Regional ICT

Regulatory Spaces

(C) Raúl L. Katz

(c) IBEI, de esta edición

Edita: IBEI

Elisabets, 10

08001 Barcelona

Tel. 934121189

Fax. 933040071

E-mail: ibei@ibei.org

URL: www.ibei.org

Depósito legal: B-21.147-2006

ISSN: 1886-2802

Imprime: Ediciones Gráficas Rey, S.L.

Barcelona, January 2014 


\title{
THE EMERGENCE OF REGIONAL ICT REGULATORY SPACES
}

\author{
Raúl L. Katz
}

Abstract: This paper examines the role that existing Latin American policy institutions and regulatory coordination mechanisms (otherwise referred to as "regional regulatory spaces") play in innovation and development of the ICT sector. In doing so, it recognizes that sector regulation does not currently match regional development, thereby limiting its potential progress. In order to shed light on the role that the "regional regulatory space" could potentially play, the author addresses three main questions:

- Is there a hierarchy of policies by which it is presumed easy to "coordinate within well-defined technical subjects" but extremely challenging to "agree in matters of public policy?"

- What would happen if policy divergence became more important than convergence? Is it reasonable to consider creating "regional regulatory spaces?" or should we focus solely on technological coordination?

- Do institutions capable of serving as effective regional regulatory spaces already exist in Latin America or should we consider modifying existing institutions or creating new institutions?

After analyzing these three overarching areas of concern, this paper then discusses the need to create a regional space in order to harmonize ICT regulatory frameworks and public policies. Ultimately, this work aims to advance the institutional formulation beyond pre-existing efforts.

Keywords: Latin America, public policy, telecom, ICT, regulation, innovation, development.

Comments: Paper presented at the IBEI-CEPAL international seminar "Innovación y regulación en las TIC.Una perspectiva comparada entre Europa y América Latina". Barcelona, 30 September - 1 October 2013. 


\section{INTRODUCTION}

This paper identifies the existing policy making institutions and the regulatory coordination mechanisms (the so-called "regional regulatory spaces") within the Latin American information and communication technology (ICT) industries and analyzes their role in stimulating innovation and development. It asserts that sector regulation is not in line with regional development, thereby creating artificial barriers to progress. In this context, the paper differentiates between the formulation of integrated holistic public policies (such as the deployment a regional Internet interconnection architecture) and the mere regional technical coordination necessary in order to encourage more efficient sector performance. As such, this work considers the suitability of regional regulation spaces within two levels: 1 ) the definition of public policies that stimulate ICT sector development and 2) the coordination of integrated and efficient technological development (such as the prevention of interference when managing spectrum).

Furthermore, the premise of this paper (the need for "regional regulatory spaces") incorporates a series of implications that will be treated as hypotheses. First, at a fundamental level, a conceptual equivalence is implicitly assumed between 1) the regional development of public ICT policies and 2) that which will henceforth be referred to as technological coordination (defined as the coordination of spectrum assignment, numeration, technological standards, etc.). To what extent are these two conceptual policy domains equivalent? Alternatively, is there a hierarchy of policies by which it is presumed easy to "coordinate within well-defined technical subjects" but extremely challenging to "agree in matters of public policy?"

Secondly, the paper assumes that structural forces within the region drive regulatory convergence, largely due to the subsequent need for "regional regulation spaces." What would happen if policy divergence became more important than convergence? Within the context of policy divergence, is it reasonable to consider the possibility of creating "regional regulation spaces?" Or, alternatively, should we focus solely on technological coordination, leaving each country in charge of defining its own public policies?

Third, this paper understands that the establishment of "regional regulatory spaces" could become the variable needed to improve national ICT regulation and policy making in Latin America. In other words, this work examines the possibility that regional regulation could play a positive and meaningful role in the development of national policy frameworks. ${ }^{1}$ In this sense, one could conclude that even if

1. See Jordana, J., Levi-Four, and Pig, I. (2005). The limits of Europeanization: regulatory reforms in the Spanish and Portuguese Telecommunications and Electricity Sectors. European Integration online Papers (EIoP) Vol. 9 (2005) No 10; http://eiop.or.at/eiop/texte/2005-010a.htm. 
the divergent ICT policy tendencies outweigh the convergent forces (in other words, "what separates us in matters of ICT policy is larger than what unites us"), the "regional regulation spaces" could still play a positive role by fostering the dialogue and experience sharing environment that could contribute to a convergence in policies. While one could say that regional regulatory spaces are limited in their ability to build a convergent environment, there is such a need for a regional agenda that there is no other choice than to face their development and promotion head on. In regards to this last hypothesis, do the institutions capable of serving as effective regional regulatory spaces already exist in Latin America or should we consider modifying or creating new institutions?

This paper will first approach these three questions, trying to shed light on the role that the "regional regulation space" may come to play. After analyzing these three hypotheses, we will then discuss the need to create a regional space in order to harmonize ICT regulatory frameworks and public policies.

\section{TECHNICAL COORDINATION VERSUS PUBLIC REGIONAL POLICIES}

A "regional regulatory space" may respond to two different types of objectives. Associated with the principle of international harmonization, the first objective assumes that positive externalities stimulate cooperation among nations. ${ }^{2}$ In this instance, when developing public policies, nations renounce their complete autonomy because they recognize that the benefits of coordination outweigh total independence. In other words, while this coordination does bring some constraints, the benefits of developing an efficient ICT infrastructure far outweigh these drawbacks.

The clearest example is seen in the countries' coordination in managing interference when assigning radio electric spectrum. As countries recognize the benefit of reducing interference at their borders, the operators who provide service in each country in turn may face constraints in terms of spectrum assignment.

2. See Dolowitz, D.P. and Marsh, D. (2000) 'Learning from abroad: the role of policy transfer in contemporary policymaking', Governance 13: 5-24. 
It is important to recognize that technological coordination among countries does not necessarily imply an imposition of one country's approach on neighboring countries (although in certain cases it may exist de facto when one of the neighboring countries has much more economic power). The process of technological coordination involves negotiation between states that tends to balance regional objectives and national goals. In many cases, this negotiation may not result in a successful resolution because each party is driven by contradictory objectives. The definition of digital television standards, where industrial policy considerations could condition opposing approaches, serves as an example of this situation. However, in most cases, technological coordination tends to yield positive results (in a way that resembles the sequential iterations of the Prisoner Dilemma game ${ }^{3}$ ).

The formulation of regional ICT public policies, on the other hand, responds to a more complex process. As a starting point, it presupposes a certain degree of political or economic integration. In the field of economics, shared objectives (economic growth) or international competition (which spurs a response to a disadvantage in the balance of trade) guide integration. In this sense, the alignment of regional policy objectives extends far beyond the aforementioned bilateral coordination. In this context, when formulating regional public policies, each country evaluates the benefits and risks of "mercantilist" autonomy and integrated development. However, as more nations take part in this process, the more complex it becomes and, in turn, success is less probable. For example, reaching an agreement on roaming rates or Internet interconnection framework requires a much more complex alignment of economic policy objectives than simply coordinating radio frequency spectrum assignment in border zones.

In sum, technological coordination is easier to achieve than the formulation of regional ICT policies. In fact, research has shown that the convergence of public policies or regulatory frameworks is more likely to occur when the objective involves a clear decision (for example, spectrum assignment). On the other hand, if the policy is formulated based on general principles, thereby allowing each country to formulate its own policy instruments and implementation mechanisms, the probability of success diminishes substantially. In this manner, technological coordination and the formulation of regional policies within the creation of "regional spaces" assumes a risk of replicating one of the numerous examples of Latin American coordination failures.

3. See Axelrod, R. (1984) The evolution of cooperation. NY: Basic Books. 


\section{CONVERGENCE VERSUS DIVERGENCE IN THE DIFFUSION OF PUBLIC POLICIES}

The creation of a "regional regulation ICT space" assumes there is a need to promote the diffusion of common public policies within a process of convergence. Levi-Faur and Jordana define convergence as the process that leads to the adoption of common regulatory frameworks and similar policies, while divergence suggests the formulation of autonomous policies based on the trajectory and idiosyncratic roots of each country. ${ }^{4}$ Along these lines, convergence presupposes a certain similarity among countries in terms of their policy objectives, which include content, political instruments, and styles of governance.

Levi-Faur and Jordana introduce the concept of divergent convergence, wherein the public policy diffusion process may simultaneously involve convergent and divergent tendencies. While certainly possible, we consider it necessary to determine which of the two tendencies is more important. For example, if divergence exists around "nontrivial" policy domains, the creation of a "regional regulatory space" may be unviable.

For this reason, when considering the viability of a "regional regulatory space," it is important to assess the relative importance of forces that might encourage divergence (we label these forces "centrifugal") or convergence ("centripetal" forces), promoting greater coherence in the adoption of regional public policies. If the forces that encourage divergence are stronger than those forces that oppose them, the possibility of success in the creation of a "regional space" will be severely limited. We will now examine the "centrifugal" and "centripetal" tendencies that occur in the Latin American ICT sector.

\subsection{Tendencies that encourage convergence in the diffusion of ICT public policies}

By definition, a "centripetal" tendency drives convergence of ICT public policies. These forces encourage the different agents who are formulating the public policies to share ideologies, symbolical codes, and beliefs, fostering a learning process and experience sharing supported by a "regional regulation space." In this case, we identify three forces.

4. See Levi-Faur, D. and Jordana, J. Regulatory capitalism: policy irritants and convergent divergence. 


\subsubsection{Diffusion of regulatory models}

Since the 1980s, at an international level, the convergence of ICT policies has been guided by a process of diffusion of the frameworks and models developed initially in mature countries. Through this process, public policy implementation tends to follow a predetermined path of imitation determined by political, cultural, and local geopolitical parameters as well as by "herd behavior." ${ }^{5}$ For example, the adoption of two regulatory models in telecommunications - the creation of a regulatory authority and the privatization of the incumbent - may be graphed in an $S$ curve similar to the one observed in the case of innovation diffusion (see figure 1).

Figure 1. Diffusion of Regulatory Models in Telecommunications (Number of adopting countries)

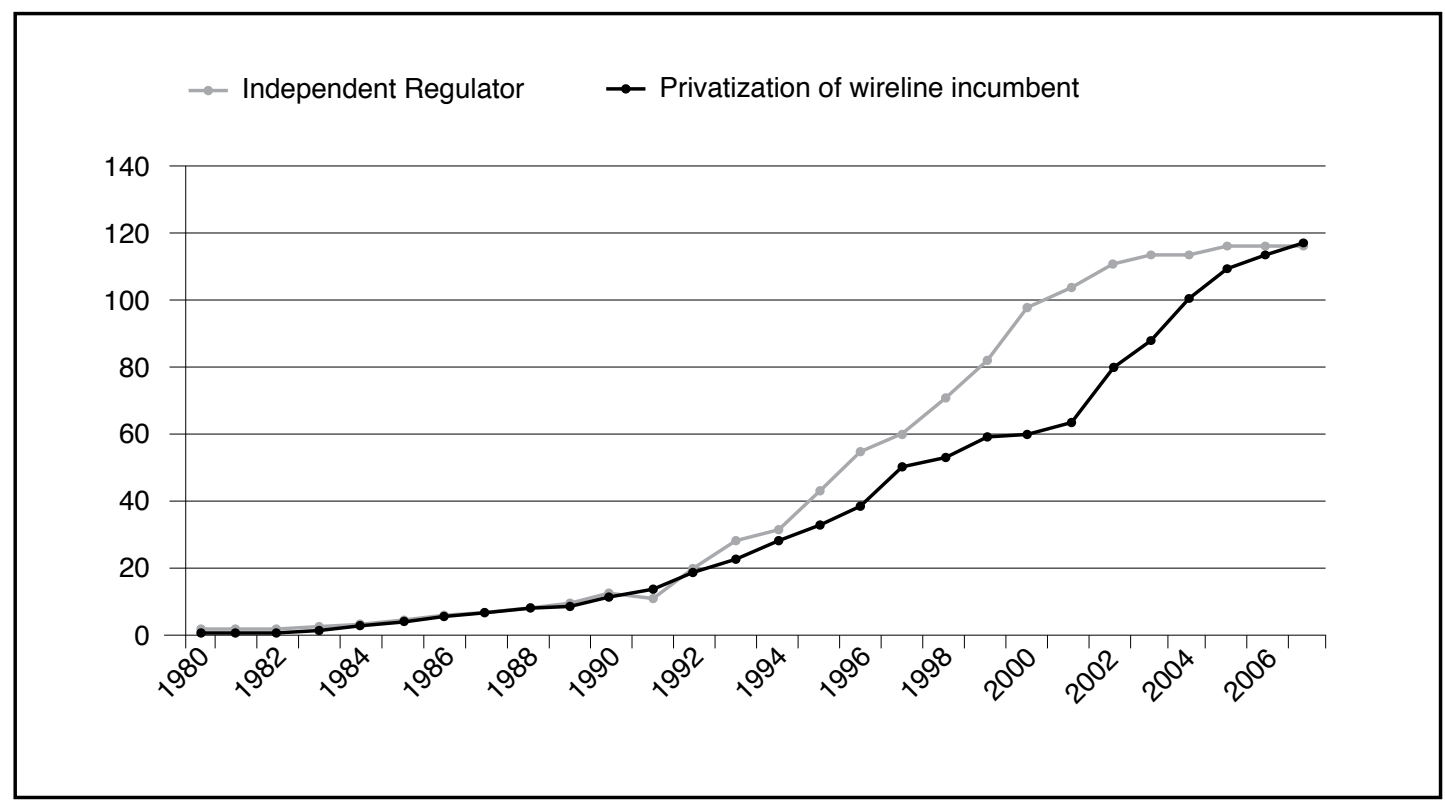

Source: ITU

Figure 1 shows that, after the incubation period that extends from 1980 to 1992, the adoption of both policy initiatives (privatization and regulation) accelerated globally. This phase of accelerated diffusion culminates in 2002 for the creation of independent regulatory agencies and in 2005 for the privatization of incumbents. Thus, these two key changes to the telecommunications regulatory framework were diffused globally - reaching 120 countries - within a 25-year period.

5. See Levi-Faur, D. y Jordana, J. op. cit. 
While the process of public policy adoption among governments is based on communication behavioral patterns similar to those that occur between individuals when it comes to innovation diffusion (where the process may also be plotted in an $S$ curve), it is important to emphasize that the diffusion of regulatory models is not necessarily guided by random social interactions. Indeed, we believe policy diffusion to be a much more deterministic process following three mechanisms. The first one is the so-called geographic proximity effect, whereby the diffusion of public policies is predetermined by the similarity of the situations and challenges of neighboring countries. If Country $X$ faces challenges similar to those challenges of neighboring Country $Y$, it is highly likely that the government of Country $X$ will adopt policies previously implemented by Country $Y$. This behavior results from the geographical proximity that allows public officials to interact frequently, a process known as "copying your neighbor." The term was first introduced to explain the diffusion of water treatment policies in municipal administrations in the United States in the 1960s.

The second regulatory model diffusion mechanism is called the "lateral diffusion mechanism," whereby the imitation of models and policy frameworks is the result of several countries either sharing the same cultural background or operating within the same social and economic context. The difference between the geographical proximity and the lateral diffusion mechanisms is that in the second case, both countries do not necessarily have to be neighbors so long as they have similar social and economic and political systems.

The third regulatory and policy diffusion mechanism is the so-called hierarchical diffusion effect. As its name indicates, central countries initially introduce public policies that are then later adopted by peripheral nations that follow the lead of more mature nations. To conclude, when looking at public policy adoption, what may seem to be a random process is, in reality, a result of diffusion determined by the combination of the three pre-defined forces: geographic proximity, lateral diffusion, and hierarchical influence.

The processes described above may be rationalized in order to demonstrate that policy formulation is more than simply imitation (see table 1): 
Table 1: Rationale in the diffusion of regulatory models.

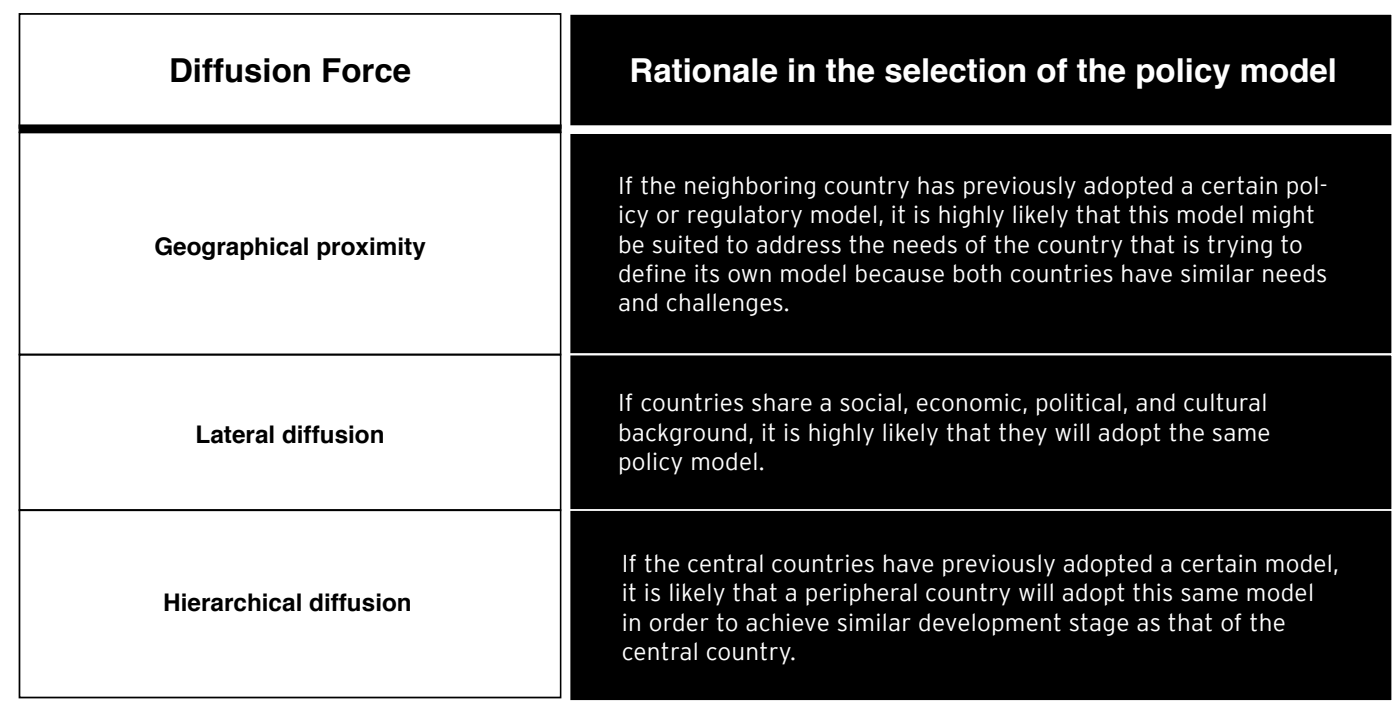

As multiple countries adopt the same policy or regulatory framework and the diffusion process gains momentum, we can observe the phenomenon that Levi-Faur refers to as "herd behavior." The need to reduce uncertainty in the policy-making process (which results from imitating a leading country), the imperative to reduce information costs (policy imitation reduces the need to analyze the specificities of the adopting country), and the legitimization provided by the opinion leaders of the country that originally espoused the model may all guide the herding process. ${ }^{6}$ As such, the selection of a specific regulatory model or policy framework is determined not by the available information and analysis of the situation, but instead by a process of imitation. In this sense, the leading countries influence the behavior and cognitive framework of the nations adopting a new public policy. When these signals and changes in policy lead to convergence of an important number of countries, we then witness herd behavior.

In terms of the transfer of regulatory and policy frameworks, herding exhibits several peculiar effects. For one, numerous countries undertake similar policy decisions (e.g. the privatization of the predominant telecommunications operator) within a very short period of time. Underpinning this process is a spreading mechanism that facilitates the diffusion of the model. Secondly, we also see incentives to imitative behavior. For example, a certain policy may have greater value as more countries choose to adopt it. In other words, one country may think, "if all these countries have privatized, we can't go wrong by imitating them." This rationale is known as the stimulus of uncertainty reduction. Herding also enhances the reputation of the

6. According to Levi-Faur and Jordana, "Most cases of diffusion are based not on rational learning but on a myriad of mechanisms in which the rational component, if any, remains small” (Levi-Faur and Jordana, Regulatory Capitalism: Policy Irritants and Convergent Divergence). 
policy makers of the country adopting the new policy ("by privatizing the operator, we behave in the same way as all of these other important countries who have done so before"). Finally, herding reduces the costs of obtaining the information and analysis required to make an informed public policy decision, (we could label this as the value of the "benchmark"). Certain neo-institutional sociologists (Jepperson and Meyer, 1991; Meyer, Boli, Thomas, and Ramirez, 1997) have studied the process by which policy makers imitate their counterparts in other countries in order to reduce research costs and profit from legitimization.

Within the public policy diffusion process, the behavior of specific countries may also determine the adoption of certain models. In this context, there exist "leader" countries (that set an example that other nations tend to follow) and "follower" nations (who appear more conservative in implementing policy changes). In fact, Levi-Faur has divided countries into three groups: "instigators" of regulatory policies, "followers," and "laggards."

The policy makers in instigator nations do not rely on previous models or examples when introducing regulatory or policy framework changes. As such, instigators may, at the same time, be categorized as leaders or radicals. Leader states adopt a certain regulatory model at the beginning of a diffusion process, significantly influencing imitation and legitimacy. The United Kingdom, for instance, may be considered a telecommunications policy instigator. The privatizations of both Cable \& Wireless (1981) and British Telecom (1984), the creation of independent regulatory agency Oftel (1984), market liberalization (1991), and the functional separation of BT (2005) all significantly influenced the adoption of similar policies by other countries. International credibility was also based on the fact that the changes in regulation were not associated with a unique political orientation; they were, in fact, initiated by a conservative administration and continued by a Labor government. At the same time, Great Britain is generally viewed as a nation with high regulatory capacity (technologically, economically, and legally).

Countries that follow the instigators' examples do not want to assume the risk of innovation when formulating their own regulatory frameworks. They tend to adapt to collective norms previously formulated by transnational institutions. Amongst the follower nations, Levi-Faur includes moderate and indecisive countries. In moderate countries, public administrators and politicians adopt a pragmatic rather than an ideological attitude when formulating regulatory policies. While these countries possess regulatory capacity, the adoption of new models tends to take place following an extensive process of evaluating their needs and the examples set forth

7. This categorization is based on work conducted by Levi-Faur, D. Herding towards a New Convention: on herds, shepherds and lost sheep in the liberalization of the telecommunications and electricity industries. 
by the "instigator" nations. Germany serves as an example of a moderate country. The privatization of Deutsche Telecom, the creation of an independent regulatory authority, and the liberalization of markets happened gradually, in part following the experiences of Great Britain, the United States, Japan, and South Korea.

The indecisive follower countries lack the regulatory capacity or the policy framework necessary to formulate telecommunication policies in the way that moderates can. Examples of other countries serve as their only point of reference. Therefore, the indecisive countries tend not to implement a certain policy until the number of adopters in the diffusion process reaches a tipping point (critical mass). This behavior is fairly similar to that of the laggards, but in the case of the laggards, the critical mass (number of prior adopters) is larger than in the case of indecisive countries.

Interestingly, the positions of the instigator, the follower, and the laggard are not static but may in fact change through time. For example, in terms of Latin American telecommunications, Chile was an instigator of privatization policies in the 1980s and, therefore, an example to observe and to follow. Indeed, Chile was one of the first countries in the world to privatize and liberalize its telecommunications industry. However, the Chilean example has been generally discredited in more recent years for three reasons. First, the reforms were initiated under a military dictatorship with extreme neoliberal economic policies. Second, the Chilean economy is small compared to many emerging countries and Chile's example is not applicable to larger markets. Finally opening the markets resulted in a period of extreme frictional costs as the first private buyer of the telecommunications operator prematurely retreated under conditions of crisis.

On the other hand, other Latin American countries have now become examples to be followed by their regional counterparts in terms of their ICT regulation and policies. Uruguay, for instance, has notably promoted the development of high technology in the context of state ownership of the incumbent. Meanwhile, Costa Rica has achieved a high rate of technological development through a combination of market liberalization policies and an independent regulatory authority.

Beyond the factors mentioned above, the individual characteristics of each country and the institutions with which its policy makers are affiliated determine the diffusion and convergence of public policies. Affiliations are essential to the topic of this paper insofar as they make reference to the role of regional regulatory spaces. In this regard, public policies and regulatory mechanisms are diffused through in-

8. Chile began the privatization of its telecommunications sector in 1982, concluding the sale of its long-distance operators (ENTEL) as well as local (CTC) in 1985. An embryo of an autonomous regulatory agency was created in 1977 and the telecommunications market was liberalized in 1991. 
stitutional networks that facilitate the transfer of models. The institutions involved in the diffusion of public policies and regulatory frameworks within the ICT arena fall into one of three categories. First and foremost, transnational institutions (such as the European Commission, OECD, the World Bank, ${ }^{9}$ the United Nations, ECLAC, Organization of American States, CAF, and Inter-American Development Bank) play a key role in the transmission and promotion of regulatory framework and public policy recommendations. ${ }^{10}$ Second, public policy "entrepreneurs" are accounted for (consultants, experts, nongovernmental organizations) and should be viewed as promoters of "better practices" and "benchmarks." Third, we must also consider international organizations, both from inside the ICT sector (Regulatel, Berec) and outside it (Commonwealth, UNASUR). This way, the institutional factor (or the "regional regulation spaces") plays an important role in the promotion of policy convergence.

To conclude, policy diffusion processes, by means of their multiple mechanisms, represent a powerful force of convergence in ICT regulatory and policy frameworks. However, they are not the only force. Other factors will be examined in turn.

\subsubsection{Regional expansion of global operators}

Multinational enterprises, the second force, also drive the convergence of ICT regulatory and policy models. Considering the presence of global telecommunication operators throughout the Latin American countries, two forces may operate simultaneously to encourage the adoption of common public policies. These corporations act as policy advocates, promulgating those rules and policies that encourage profit, a concept known as "convergence driven market penetration." Bennett (1991) illustrated this mechanism by referring to the action of multinational corporations that pressure governments to harmonize regulation as it relates to their products.

At the same time, as a result or occasionally even as a preemptive move, countries may launch policies or regulatory framework to respond to competitive pressures from other nations in an effort to offer more attractive conditions for global operators. Holzinger and Knill (2005) labeled this process as convergence under regulatory competition.

Thus, as either a reaction to the advocacy of multinational corporations or as a means to promote a favorable foreign investment environment, policy makers may introduce ICT policy and regulatory initiatives, reflecting an additional convergence force.

\footnotetext{
9. See for example, the role that the World Bank fulfilled through the activity of its representative E.W. Kemmerer, in the promotion and development of financial institutions in the Andean region.

10. The regulatory entities for telecommunications in Brazil and Argentina are designed according to the norms of better practices of the World Bank.
} 


\subsubsection{Economies of scale in technology investment}

In telecommunications, scale economies also drive convergence of ICT regulatory and policy initiatives at multiple levels. In the first place, the objective of reaching a critical mass in order to secure a return to scale drive the unification of regional economic spaces to foster the economic sustainability of multinational telecommunications operators. Depending on the point of view of regulatory competition, certain nations may be incentivized to create common economic spaces to promote investment in the development and sustainability of telecommunications operators. The paradigmatic example of this tendency is represented by the actual discussion in the matter of a common telecommunications market for the European Union.

Economies of scale also act as a stimulus for the convergence of ICT policies in terms of the selection of standards and technologies. So long as the production volume of a given product is indirectly related to the cost per unit of the equipment, a country has incentives to select a similar technological standard as the one previously adopted by other countries in order to benefit from lower costs in the acquisition of the equipment, which in turn makes ICT products and services more affordable. The adoption of common digital television standards, which results in a reduction of the unit cost of set-top boxes, serves as an example. The selection of norms for fourth-generation mobile carriers is another example.

Obviously, the size of regional economies impacts the importance of this variable when promoting policy convergence. For example, Brazil has little incentive to consider the public policies of neighboring countries when selecting a standard; by virtue of its size, it already finds itself well beyond the inflection point of the ICT scale economies curve. At the other end of the spectrum, Central American countries have a multitude of incentives to unify the markets in order to boost investment and reduce the costs of equipment.

\subsection{Tendencies which drive the divergence of public policies}

So far we have reviewed the three forces that drive a convergence of ICT public policies: imitative diffusion, multinational private players, and economies of scale. However, other forces may play a "centrifugal" role. They are oriented towards promoting divergence and, consequently, autonomous policies and behaviors. 


\subsubsection{Divergent national economic dynamics, interests, and objectives}

The prior section of this paper dedicated to convergent forces discusses the role of institutions that act as platforms for the transmission of certain public policies. As an alternative view, it is important to consider the possibility that such institutions may lose a certain degree of coercive power or influence. This may occur partly as a result of economic changes that erode the relevance of certain institutions. For example, if the financial conditions of the nation do not manifest a need for multilateral organizations (e.g. the IMF) in order to renegotiate external debt (as was the case with South Korea at the time of the Asian crisis), the influential capacity of such organizations diminishes substantially.

In the same vein, if the nation's trade patterns are reoriented in terms of products and flows, the interest or the pressure to modify the regulatory framework to satisfy the needs of buyers is greatly reduced. This example clearly occurs in Latin America as the proportion of the region's foreign trade oriented towards China has increased in comparison to its trade with the United States. In this sense, countries in the region see less urgency to adapt their ICT regulatory and policy framework to cater to the interests of the United States or Europe. In fact, the trend toward the reentry of the state in the Latin American ICT sector directly correlates with the "decoupling" of Latin American economies with respect to the northern hemisphere and their realignment with Asia.

\subsubsection{The role of the state and the swing of the pendulum back toward the service provider state}

After the wave of privatizations in the 1990s, Latin American countries are now split between two groups in regards to state participation in the sector. Led by the experience of past public policies, one group of countries believes that the provision of retail telecommunication services must be in the hands of the private sector. These countries include Argentina, Brazil, Chile, Colombia, Peru, and Mexico. On the other hand, the other group of countries believes that the state must be involved in the provision of telecommunications services. This group includes Uruguay, Costa Rica, Ecuador, Venezuela, and Bolivia. It is important to emphasize that this last stance does not necessarily mean the monopolization of service. In Costa Rica and Ecuador, for instance, the state operator competes with private sector operators in the fixed broadband market; in all other countries, multiple players comprise a vibrant wireless industry. 
On the other hand, even in countries where the private sector has been the fundamental agent of retail service provision, the state has once again entered the sector through the creation of fiber optic backbone networks. For example, the Brazilian government-owned Telebras enterprise tends to focus on the deployment of networks in an effort to secure the provision of telecommunications services in isolated regions. ${ }^{11}$ On the same note, as part of its National Plan "Connected Argentina," Argentina is deploying a $25,000 \mathrm{~km}$ long national fiber optic network operated by the state enterprise ARSAT. 12 In Colombia, "Grupo Azteca" won a government-sponsored bid to build a 15,000 km fiber backbone network and connect 1,078 municipalities. In a similar vein, the Peruvian government approved the construction of a national fiber optics backbone network, focusing primarily on providing service in rural, isolated zones. Coincidentally, in July 2012, the government of Venezuela announced the construction of an 18,000 km national fiber optics backbone network, bringing broadband coverage to $90 \%$ of the population.

In conclusion, what at the end of the 1990s largely seemed to be a consensus in regards to the agent that should lead the deployment and provision of telecommunication services process, Latin America has since assumed a more divided position where one group of countries recognizes the directive role of the private sector, while the other recognizes the primary role of the state in the sector.

\subsubsection{National security}

Although this divergent tendency may have existed as early as the initial deployment of international data networks that took place in the $1980 \mathrm{~s}^{13}{ }^{13}$ it has assumed a new level of importance with recent revelations of cyber espionage. Believing that any storage of information on servers located outside the physical borders of a country increases the possibility of cyber espionage, numerous Latin American countries advocate for ICT policies that would allow them to control the flow of information by restricting its storage and processing outside of the national territory.

This tendency encourages the divergence of public policies with respect to the model proposed by several of the more mature countries. It promotes mercantilist and autonomous behaviors that are also reflected in the Internet governance discussion.

\footnotetext{
11. The Telebras network is being jointly extended throughout the Brazilian national territory. As of June 2013 the fiber optics network had an extension of $25.000 \mathrm{kms}$. interconnecting 1.300 municipalities. This past year, Telebras built $8.900 \mathrm{kms}$. joining together the state capitals of Sao Paulo, Rio de Janeiro, Belo Horizonte and Vitoria. Continuing the deployment of a national level in March of 2013, President Rousseff announced a network expansion project for an investment sum of US $\$ 25$ billion for the next 10 years, which will include public and private associations, tariff reductions and credits from the BNDES.

12. The Argentinian government allocated an investment of US $\$ 1,314$ bn for the year 2013 to finance their plan. The investment is estimated to reach approximately US $\$ 3$ bn in the next three years. In association with Arsat, the provincial government of Neuquén will build $1.200 \mathrm{kms}$ of fiber optics networks.

13. Recall the discussion of international data flows.
} 


\subsubsection{Policies of Internet governance}

The WCIT conference that took place in Dubai in December 2012 demonstrated the dividing line that exists within the communities of countries in regards to Internet governance. ${ }^{14}$ The opposing camps focused on the role of governments and the ITU in managing the Internet. The countries that signed - including China, Russia, Iran and some Arab and African countries (as well as several Latin American countries) - want more government control over the flow of information, the registry of domains, and the monetization of the Internet. Those countries that didn't sign the treaty did so under the suspicion that this regulation against spam and over network security could lead to network censorship and monitoring.

The list of countries that signed (and did not sign) the final documents shows the degree of divergence that exists within the Latin American region (see table 2).

Table 2. WCIT: Latin American signatories and non-signatories of the final documents.
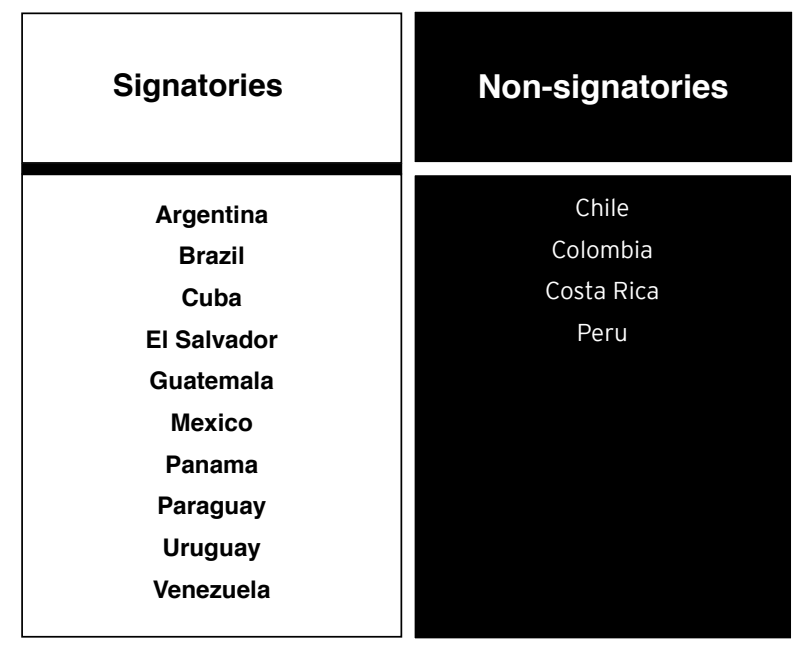

The list of signatories and non-signatories in Latin America partially relates to each country's respective degree of state control over the Internet, a vision guided by different political philosophies (autocracy versus democracy). Cuba and Venezuela, for instance, have signed the documents. However, many Latin American countries signed not out of a desire to increase governmental control over the Internet, but rather because they estimated that their support could increase access to Internet, subsequently, reducing the digital divide. ${ }^{15}$ At the same time, Uruguay, the most

\footnotetext{
14. Recall the discussion of international data flux.

15. Aguerre, Carolina. "Beyond Dubai: Post WCIT Reflections from an Internet Governance Viewpoint." LSE Network Economy Forum. London School of Economics, 4 Apr. 2013. Web. 16 Sept. 2013. $\leq$ http://blogs.lse.ac.uk/nef/2013/04/04/postwcit-internet-governance/>.
} 
democratically developed country, also signed. The group of non-signatories is more coherent in terms of political philosophy. However, Latin America exhibits a clear divergent philosophy of Internet governance.

\subsubsection{A perception that the ICT policy model of mature countries has run its course}

The previously discussed process of regulatory model imitation refers to recipient countries' (model "importers") perception that not every leading country experience has yielded positive results. Notable examples include the United States' local loop unbundling and the United Kingdom's structural separation of the incumbent. Ex post facto evaluation of these experiences indicated that, from the point of view of the original objectives and partly due to technological changes that took place after the adoption of the policies, these initiatives did not yield positive results. This evaluation has resulted in a position that rejects the model based on the analysis of the impact of the policies in other geographies. This rejection could be based on the analysis of the aggregated results of a given policy. For example, when defining a digital policy, the limited results generated so far by the Digital European Agenda ${ }^{16}$ may force some countries to question the European Union's assertion regarding the promotion of next generation networks.

In this sense, when defining their public policies, countries may question the proposed model and opt for divergent alternatives due to the perception that some of the leading countries' models have not generated optimal results. In this sense, the countries can learn from the best practices of other countries while recognizing and taking into account the negative experiences when making their own policies and decisions.

That said, not all Latin American countries, however, share the view that the European model has run its course. For example, some countries still consider competitive remedies such as local loop unbundling and structural separation of the incumbent within a service-based competition paradigm, while others feel that infrastructure-based competition is the most appropriate policy.

16. See Katz, R. "Investment, infrastructure and competition in European telecommunications", Intermedia May 2013, volume 41, issue 2. At the end of the year 2012, in spite of the ambitious goals of the Digital Agenda, only $11 \%$ of the population had coverage of domestic fiber optics, while the amount of fiber optic users within the 27 nations of the European Union totaled only 6 million. On the other hand, users of DOCSIS 3.0 high-speed broadband connection amounted to 7,5 million. Fourth-generation LTE networks provided coverage for only $1 \%$ of users, projecting to reach $20 \%$ by the end of 2017 . This coverage may be compared to the actual coverage in Korea (20\%) and the United States ( $8 \%)$. 


\subsection{Conclusion regarding divergent convergence of Latin American ICT policies}

Just as Levi-Faur and Jordana anticipated, divergent convergence in the Latin American public policy and ICT regulation field clearly exists. The following table summarizes the different forces and demonstrates the tension that arises when countries face contradictory pressures, thereby reducing the degree of efficiency and consistency in the formulation of public policies (see table 3).

Table 3. Convergent and divergent forces in ICT policy in Latin America
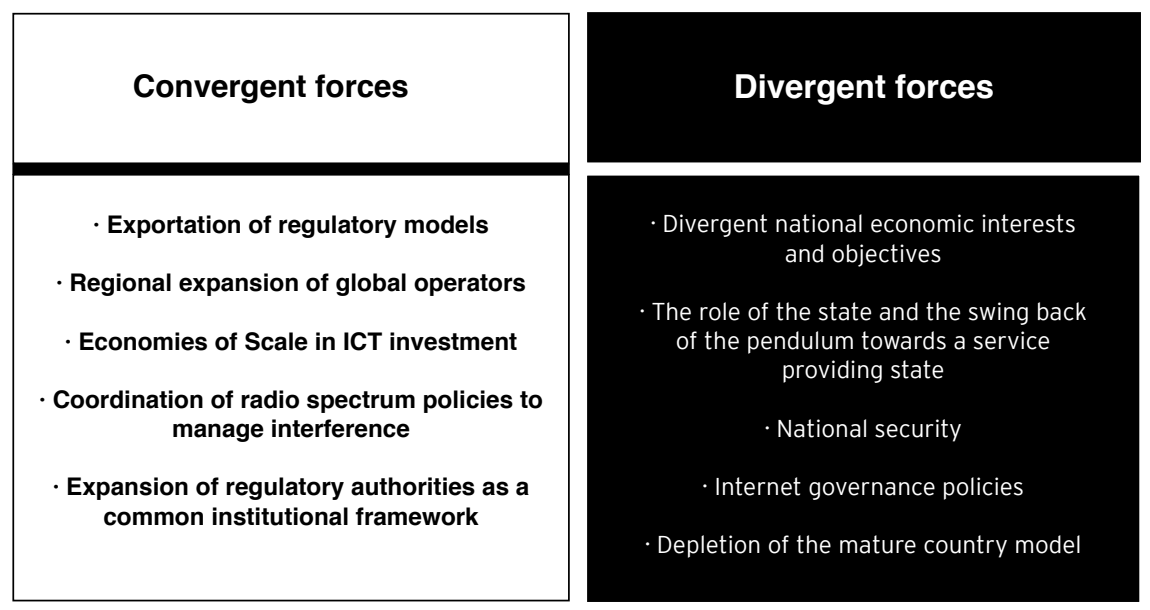

Going back to the concept of divergent convergence, the divergent tendencies may be characterized as fundamental and nontrivial, which reinforces the need to construct regional spaces where the dialogue between policy makers will allow us to build on the "centripetal" factors and limit the impact of "centrifugal" tendencies. 


\section{THE POSITIVE CONTRIBUTION OF A REGIONAL REGULATION SPACE}

Academic research has determined that a series of mechanisms - ranging from the imposition of a predetermined regime to the rational analysis of options and their impact - guide the diffusion of public policies (Dolowitz \& March, 1996, 2000). In the first case, the adoption of a policy is defined as one of "coercive transference," while at the other end of the spectrum it is defined as "voluntary transference." The role of institutions in the diffusion process of regulatory models varies based on their level of influence, ranging from a coercive imposition to a voluntary transfer based on the assimilation of information. For example, imposition occurs through mechanisms of conditionality (privatizing an operator as a condition for the grant of credit). On the other end of the spectrum, an institution can only facilitate the diffusion of regulatory model information. Between these two extremes, we find coercive attitudes (obligatory adoption of a certain model imposed by obligations established by international agreements) as well as more voluntary attitudes that also recognize an unavoidable necessity (liberalizing the telecommunications market in order to send the message to the capital markets that the country wants to promote direct foreign investment). ${ }^{17}$ This scheme allows us to piece together the way that the diffusion of ICT policies has been adopted in different contexts (see figure 2).

Figure 2. The role of institutions and the transfer of regulatory models

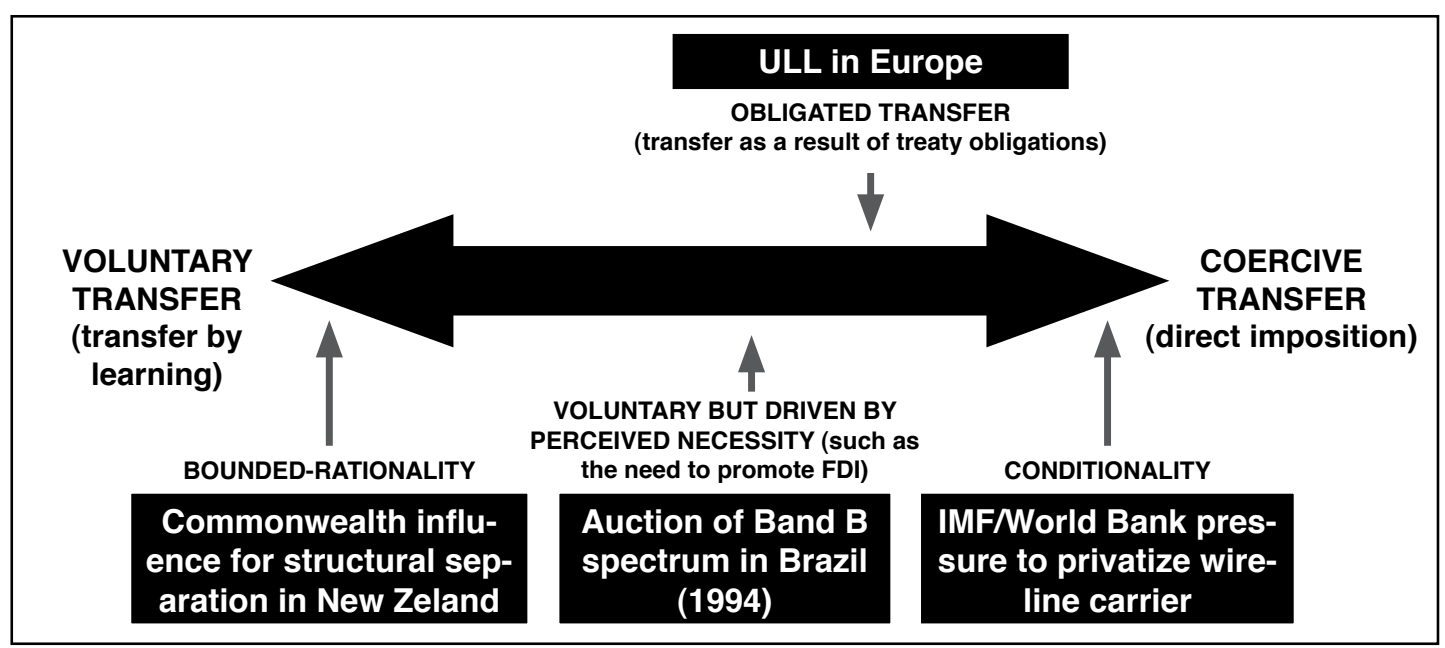

Source: Based on Dolowitz and Marsh (2000)

17. See Heinsz, W. J., Zelner, B. A. and Guillen, M. F. (2004). International coercion, emulation and policy diffusion: market-oriented infrastructure reforms, 1977-1999. William Davidson Institute Working Paper Number 713 (July 2004); Busch, P. and Jorgens, H.(2005). International Sources of cross-national policy convergence and their interactions. Paper presented at the 46th Annual Convention of the International Studies Association, March 1-5, 2005, Honolulu, Hawaii; Dolowitz, D.P. and Marsh, D. (2000). The role of policy transfer in contemporary policy-making, Governance 13 (1), 5-23. 
Table 4 clarifies the role that institutions play in promoting regulatory models (both in a coercive and voluntary way).

Table 4: Models of institutional influence

\begin{tabular}{|c|c|c|}
\hline Influence model & Mechanism & Examples \\
\hline Conditionality & $\begin{array}{l}\text { Change in the reg- } \\
\text { ulatory framework } \\
\text { as a condition for } \\
\text { access to benefits }\end{array}$ & $\begin{array}{l}\text { The IMF's role in promoting } \\
\text { the privatization of telecommuni- } \\
\text { cation operators as a condition to } \\
\text { access credit lines }\end{array}$ \\
\hline Obligatory adoption & $\begin{array}{l}\text { Change in the } \\
\text { regulatory frame- } \\
\text { work imposed by } \\
\text { international treaty } \\
\text { obligations }\end{array}$ & $\begin{array}{l}\text { Adoption of unbundled local loop } \\
\text { policies in the European Union }\end{array}$ \\
\hline $\begin{array}{l}\text { Voluntary adoption } \\
\text { alluding to an unavoida- } \\
\text { ble necessity }\end{array}$ & $\begin{array}{l}\text { Change in the } \\
\text { regulatory frame- } \\
\text { work as a direct } \\
\text { result of a perceived } \\
\text { need for benefits }\end{array}$ & $\begin{array}{l}\text { Auctioning of the B band spec- } \\
\text { trum in Brazil in } 1994 \text { to signal to } \\
\text { the capital markets the country's } \\
\text { desire to open the economy to } \\
\text { direct foreign investment }\end{array}$ \\
\hline $\begin{array}{l}\text { Voluntary adoption } \\
\text { influenced by informa- } \\
\text { tion diffusion }\end{array}$ & $\begin{array}{l}\text { Change in the } \\
\text { regulatory frame- } \\
\text { work following } \\
\text { information regard- } \\
\text { ing countries under } \\
\text { similar conditions }\end{array}$ & $\begin{array}{l}\text { Structural separation of the tele- } \\
\text { communications operator in New } \\
\text { Zealand following an assessment of } \\
\text { Openreach in the United Kingdom }\end{array}$ \\
\hline
\end{tabular}

Very similar to coercion, conditional transfer of public policies, manifests itself in situations where banking institutions multilaterally impose certain conditions in order to renegotiate external debt. These conditions generally refer to the implementation of reforms, which may include the privatization of a telecommunications operator or the aperture of a telecommunications market to direct foreign investment (such as the case of South Korea in the context of the Asian crisis of the 1990s). ${ }^{18}$ In their analysis, Henisz, Zelner, and Guillen (2004) observed that the coercive transference effect is increasing, as is the range of the imposed conditions for the adoption of a particular policy.

In the absence of coercion, the availability of information as well as the learning process guide the adoption of regulatory models. The formulators of the public policies act rationally while maximizing objectives and resolving clearly exposed

\footnotetext{
18. See Heinsz, W. J., Zelner, B. A. and Guillen, M. F. (2004). International coercion, emulation and policy diffusion: market-oriented infrastructure reforms, 1977-1999. William Davidson Institute Working Paper Number 713 (July 2004); Busch, P. and Jorgens, H.(2005). International Sources of cross-national policy convergence and their interactions. Paper presented at the 46th Annual Convention of the International Studies Association, March 1-5, 2005, Honolulu, Hawaii; Dolowitz, D.P. and Marsh, D. (2000). The role of policy transfer in contemporary policy-making, Governance 13 (1), 5-23.
} 
problems. Analysis, learning, and persuasion determine this model of behavior, although it may be limited by the lack of technical resources.

Within this context, institutionalized communication within "regional regulatory spaces" may enhance the transfer of resources and analysis, the process of learning from other experiences, and the comparison of independently developed policies. For example, DiMaggio and Powell (1983) demonstrated that social and institutional structures play a positive role in the stimulation of policy convergence. In this sense, the cooperative search for solutions to specific problems (March and Simon, 1958) as well as simple organizational imitation facilitate institutional convergence.

This process contains rational decision-making elements. It is guided by an analysis of similar problems in the search for common solutions among experts with the same objectives and decision-making mechanisms (Haas, 1992; DiMaggio and Powell, W., 1991). Research also shows that while elements that trigger the convergence process may be technical and related to harmonization problems, this discussion may lead to the formulation of more generic public policies. In other words, while a regional space may initially be dedicated to technical coordination (frequency harmonization), its reach may extend to more general areas of ICT policy. ${ }^{19}$ In this context, the behavior of certain countries has led to a proactive attitude within international institutions, resulting in innovative solutions to public policy problems that have in turn contributed to the adoption of the model. The European Union, the OECD, and other international institutions have all followed this process of persuasion.

Research has also shown the positive role that "regional regulatory spaces" play, assuming three conditions are met. First, evidence that an increase in members both reduces the variance of positions and also stimulates the convergence of regulatory frameworks must guide the need to include the greatest number of countries within the regulation space. In this sense, public policy convergence depends on the interaction between political actors, which increases proportionally to the institutional density. Second, as expected, convergence of public policies increases if the regulatory space has the legal power to go beyond the declaration of its intentions. Third, the efficiency of the public policy diffusion mechanism increases if the agents involved in the transmission of models share codes and norms.

19. See Kern (2000), who shows that models of public policy are transferred in a more efficient way between members of institutions than on the basis of bilateral contracts between countries. 


\section{THE NEED FOR THE CREATION OF A REGIONAL REGULATORY SPACE IN LATIN AMERICA}

Having already demonstrated the positive impact of "regional regulatory spaces" on the convergence of ICT frameworks and public policies, we must now show the importance of their development for Latin America. Despite the number of regional institutional-level regulatory discussions in the region, convergence is non-evident. The division of Latin American signatories and non-signatories of the WCIT final document serves as a clear example of this problem.

The lack of progress toward a framework that promotes the deployment of regional Internet interconnection infrastructure serves as another example of limited public policy convergence. To expound upon this example, 63\% of all Latin American Internet traffic is comprised of outbound international traffic. Of this $63 \%, 14 \%$ is traffic amongst Latin American countries that interconnects in the United States. Another 19\% of the international traffic is used to access international content (e.g. Google (although in certain cases, these are already hosted in the region)). Latin America incurs a cost of US\$ 1.8 billion in yearly international data transports as a result of the uneven development of regional Internet connection infrastructure. Combined with the existing investments in fiber optics backbone networks, an approximate investment of US\$ 60 million may reduce international transit costs by $38 \%$. With this investment, the cost of broadband tariffs could decrease by an estimated $8 \%$ $10 \%$. From a financial standpoint, this investment is highly sustainable beyond the massive social and economic benefits that it will provide. From the standpoint of this cost/benefit equation, it is imperative to "federalize" infrastructure development and think in terms of a regional unified framework for action.

Unfortunately, the numerous recommendations by various international organizations to deploy regional Internet exchange points (IXPs), have been largely disregarded. For example, in 2000, APEC's TEL group released the ICAIS study ("International Charging Agreements for Internet Services"), identifying the need for interconnection and traffic exchange nodes. These recommendations were ratified a posteriori in the Fourth Ministerial Reunion (TELMIN 4, Annex B) in 2000, where Internet connection guidelines were published. These guidelines included recommendations for the promotion of increased interconnectivity. They also stated that governments should not intervene in the market, except when dominant enterprises or de facto monopolies exist, in which case this intervention should aim to incentivize competition. The group also felt that the parties should negotiate the prices themselves, reflecting the contribution of each network towards the communication, the usage that each party benefits from, and the end-to-end cost of the international transport. 
2001 saw the creation of the NAPLA Regional Interconnection Forum. Starting in 2006, other forums have adopted several of its recommendations, especially ECLAC. ECLAC intervened in the 2009 Internet governance forum, which took place in Sharm El Sheikh, Egypt, by raising the subject of interconnection. It emphasized that the Internet is still regarded and treated as a value-added service and that governments, especially in Latin America, have not been able to utilize traditional regulatory tools to promote the development of a more efficient interconnection.

In the same year, at its fifteenth reunion in Bariloche, Argentina, the Permanent Consultative Committee I admitted Resolution 160, which recommends the promotion of local and sub-regional interconnection nodes. It also stipulates the need for the promotion of local content development and the generation of content distribution networks ("content delivery networks") within the region. Furthermore, it also pushes for a decrease in backhaul costs.

Finally, several recommendations emerged at the Connect Americas Summit (ITU - Panama, 2012). Governments, multilateral financial organizations, private sector, and civil society organizations (NGOs) convened to propose and implement backbone infrastructures. The summit advocated for regional network development in order to increase the capillarity and support for nonprofit organizations, which would promote IXP development. The group encouraged governments to intervene in the market whenever uncompetitive practices existed. The summit also recommended the stimulation of mirror services in order to diminish international traffic and, in turn, create the local and regional content that would generate relevant uses for the Internet.

Despite these recommendations and declarations, the reality of regional interconnection infrastructure deployment shows that some countries (Brazil, Argentina) are significantly more advanced than others (Mexico, Colombia, Venezuela) in terms of IXP deployment. In conclusion, at least in the field of Internet interconnection, we observe a policy convergence that is not followed by concrete actions other than those initiatives adopted independently at the national level. Therefore, there exists, at least in this case, a need to develop "regional regulatory spaces" that go beyond the rhetoric and focus on the implementation of concrete action plans that make these declarations a reality.

Beyond the need to stimulate convergence of public policy implementation, global trends bring a sense of urgency to the need for "regional regulatory spaces." Following the WCIT conference in Dubai, a number of researchers have begun to notice the benefits of migrating Internet governance toward a "Federation" of regional units. For example, Yoo (2013) believes that decentralization of the management, governance, and development of Internet-related public policies will increase flexibility, 
innovation, and network scalability. Similarly, Noam (2013) states that the outcome in Dubai signals a beginning of the fragmentation of the web, but it does not mean the end of interoperability, which may still occur in instances such as ICANN (Internet Cooperation for Assigned Names and Numbers). Other European researchers including Drake (2013) and Kleinwachter (2013) have reiterated this belief. Drake states that, in regard to Internet governance, the global unified system of organized multilateralism is becoming obsolete in regard to Internet governance. The author emphasizes the need to establish a distributed decentralized system that promotes both cooperation and competition between regions. In this context, he sheds light upon a stage of governance and regulation composed of bilateral agreements between nations with similar philosophies and political and economic contexts.

Katz (2013), the author of this paper, agrees with Drake, but emphasizes that economic needs determine the evolution of a fragmented system of governance. One fundamental problem remains to be specified: that of giving more content and definitions to the concept of Federation in order for this to represent a significant advancement with respect to the actual system and not a mere regression to anarchy.

If we assume that the paradigm of the future is Federation, and that Internet governance is the metaphor that engulfs a major part of ICT policies, what are the implications for Latin America? Economic, geographical, and developmental interests as well as the promotion of political systems based on democratic participation require the region to be unified around certain public policy stances that should be translated into frameworks for action. The federative context determines the need for Latin America to assume a unique position not only in subjects related to Internet governance, but also in the implementation of public policies that reflect the singularity of the region. Without failing to recognize the tendencies that drive divergence between the countries of this region, the creation of "regional spaces" will help to leverage convergent aspects.

In this context, we must consider the extent to which pre-existing instances fulfill a role of "regional regulatory space" that go beyond technical coordination? This paper aims to advance the institutional formulation that goes beyond previous efforts (CEPAL, CITEL, Regulatel), although it could stem from one of the existing organizations. This coordination would imply an agreement that the scope of the discussion should go beyond technical coordination, stepping into the formulation of public policies for the ICT sector, especially in areas related to innovation. Second$l y$, it is necessary to resolve the conflict that arises between regional instances whose modus operandi is bottom-up, open, and regional, as well as the formulation of public policy at a national level that tends to be less participative. Thirdly, the new "regional space" should assume responsibilities that extend past the simple declarative dimension. Without even reaching the level of the European Commission, it would 
be useful to drive the public policy diffusion mechanisms that pursue convergence toward a dimension of "stimulated transference." While the new space will not have a legal power, it will greatly benefit from a power that allows for more than just the mere declaration of intentions. 
Aguerre, Carolina. 2013. Beyond Dubai: Post WCIT Reflections from an Internet Governance Viewpoint. LSE Network Economy Forum. London School of Economics. http://blogs.Ise.ac.uk/nef/2013/04/04/postwcit-internet-governance/

Axelrod, R. 1984. The evolution of cooperation. NY: Basic Books.

Bennett, C. 1991. What is policy convergence and what causes it?. British Journal of Political Science, 21: 215-233.

Biglaiser, G. and D. Brown. 2003. What's the Big Idea? An Ideational Explanation for Tariff Reform in Latin America, 1981-1995. In American Political Science Association. Philadelphia, PA.

Brune, N., G. Garrett and B. Kogut, B. 2004. The International Monetary Fund and the Global Spread of Privatization. IMF Staff Papers, 51.

Brune, N. and A. Guisinger. 2003. The Diffusion of Capital Account Liberalization in Developing Countries. In American Political Science Association. Philadelphia, PA.

Crain, R. 1966. Fluoridation: the diffusion of an innovation among cities. Social Forces, 44: 467-476.

DiMaggio, P.J. and W.W. Powel. 1991. The iron cage revisited. Institutionalized iso-morphism and collective rationality in organizational fields. In W.W. Powell and P.J. DiMaggio (Eds). The New Institutionalism in Organizational Analysis. Chicago: Chicago University Press.

Dolowitz, D.P. and D. Marsh. 2000. Learning from abroad: the role of policy transfer in contemporary policymaking. Governance, 13: 5-24.

Drake, W. 2013. Multistakeholderism and multilateralism. Presented at Conference A Future of Internet Governance after Dubai: are we heading to a federated Internet?. Columbia Institute for Tele-Information.

Eising, R. 2002. Policy Learning in Embedded Negotiations: Explaining EU Electricity Liberalization. International Organization, 56: 85-120.

Finnemore, M. 1993. International Organizations as Teachers of Norms: The United Nations Education, Scientific and Cultural Organization and Science Policy. International Organization, 47: 565-597.

Frank, D., A. Hironaka and E. Schofer. 2000a. Environmental Protection as a Global Institution. American Sociological Review, 65: 122-127.

Frank, D., A. Hironaka and E. Schofer. 2000b. The Nation State and the Natural Environment, 1900-1995. American Sociological Review, 65: 96-116.

Glick, R. and A. Rose. 1998. Contagion and Trade: Why Are Currency Crises Regional? National Bureau of Economic Research Working Paper 6806.

Haas, P.M. 1992. Introduction: Epistemic communities and international policy coordination. International Organization, 46: 1-36.

Henisz, W., B. Zelner and M. Guillen. 2004. International coercion, emulation and policy diffusion: market-oriented infrastructure reform, 1977-1999. William Davidson Institute Working paper Number 713, July.

Holzinger, K. and C. Knill. 2005. Causes and conditions of cross-national convergence. Journal of European Public Policy, 12 (5): 775-796.

Jepperson, R. and J. Meyer. 1991. The Public Order and the Construction of Formal 
Organizations. In P. J. Dimaggio and W. W. Powell (Eds). The New Institutionalism in Organizational Analysis. Chicago: University of Chicago Press.

Jordana, J., and D. Levi-Faur and I. Puig. 2005. The limits of Europeanization: regulatory reforms in the Spanish and Portuguese Telecommunications and Electricity Sectors. European Integration online Papers, 9 (10) http://eiop.or.at/ eiop/texte/2005-010a.htm.

Katz, R. 2013a. Investment, infrastructure and competition in European telecommunications. Intermedia, 41 (2).

Katz, R. 2013b. Internet Governance in Latin America: it is all about economics. Presented at Conference A Future of Internet Governance after Dubai: are we heading to a federated Internet?. Columbia Institute for Tele-Information.

Kern, K. 2000. Die Diffusion von Politikinnovationen. Umweltpolitische Innovationen im Mehrebenensystem der USA. Opladen: Leske $p$ Budrich.

Kleinwachter, W. 2013. The organizations for the governance of the Internet. Presented at Conference A Future of Internet Governance after Dubai: are we heading to a federated Internet?. Columbia Institute for Tele-Information.

Kogut, B. and J. Macpherson. 2004. The Decision to Privatize as an Economic Policy Idea: Epistemic Communities and Diffusion. Mimeo.

Levi-Faur, D. 2002. Herding towards a New Convention: On herds, shepherds, and lost sheep in the liberalization of the telecommunications and electricity industries. Nuffield College, Oxford.

March, J. and H. Simon. 1958. Organizations. New York: John Wiley.

McNamara, K. and E. Castro. 2003. The Diffusion of Central Bank Independence. In American Political Science Association. Philadelphia, PA.

Noam, E. 2013. A federated model for Internet governance. Presented at Conference A Future of Internet Governance after Dubai: are we heading to a federated Internet?. Columbia Institute for Tele-Information.

Roberts, A. 2003. Three Patterns in the Diffusion of Transparency Rules: Money, Guns and Human Rights. Mimeo.

Strang, D. 1990. From Dependency to Sovereignty: An Event History Analysis of Decolonization 1870-1987. American Sociological Review, 55: 846-860.

Strang, D. and P. Chang. 1993. The International Labor Organization and the Welfare State: Institutional Effects on Welfare Spending, 1960-80. International Organization, 47: 235-262.

Yoo, C. 2013. Decentralization and its discontents. Presented at Conference A Future of Internet Governance after Dubai: are we heading to a federated Internet?. Columbia Institute for Tele-Information. 